\title{
MEASURING CULTURAL VALUES AT THE \\ INDIVIDUAL-LEVEL: CONSIDERING MORALITY \\ IN CROSS-CULTURAL VALUE RESEARCH ${ }^{\mathrm{I}}$ \\ MENSURAÇÃO DE VALORES CULTURAIS NO NÍVEL INDIVIDUAL: CONSIDERANDO A MORAL NA PESQUISA CROSS-CULTURAL DE VALORES
}

\section{CHRISTIN-MELAMIE VAUCLAIR}

Doutoranda da School of Psychology da Universidade Victoria de Wellington - Nova Zelândia. School of Psychology, PO Box 600, Kelburn - Wellington - New Zealand

E-mail: melanie.vauclair@vuw.ac.nz

This work has been supported by a Victoria University of Wellington PhD scholarship. I would like to thank in particular Ronald Fischer, and also my colleagues Diana Boer, Katja Hanke, and Vivian Miu-Chi Lun for stimulating discussions and helpful comments on this manuscript. 


\section{RESUMO}

Valores compartilhados são tipicamente vistos como um dos aspectos centrais da cultura. O procedimento comum para derivar valores culturais compartilhados é feito por meio da análise das prioridades dos valores individuais no nível cultural. Este artigo delineia os problemas conceituais e metodológicos associados com esse procedimento. Descobertas feitas por meio de estudos empíricos selecionados são apresentadas para corroborar essa crítica. Meios alternativos para medir valores culturais no nível individual são apresentados e classificados em uma taxonomia de valores. Nessa taxonomia, estudos anteriores têm até agora focalizado a medição de valores por meio da importância atribuída, refletindo o que os indivíduos ou grupos sociais desejam. Contudo, argumenta-se que, se valores culturais são supostamente compartilhados, eles deveriam refletir o que é desejável, isto é, o que o indivíduo deve valorizar ou empenhar-se para alcançar como um objetivo de vida em uma determinada sociedade. Isso constitui uma nova abordagem para a mensuração de valores culturais que propõe que sejam medidos no nível individual, utilizando-se perguntas que envolvam moralidade. Sugestões são feitas sobre como os valores culturais poderiam ser operacionalizados, referindo-se aos valores morais individuais ou àqueles de um grupo social. Os benefícios da utilização de taxionomia de valores para pesquisas futuras são eventualmente descritos.

\section{PALAVRAS-CHAVE}

Valores; Cultura; Moralidade; Mensuração; Teoria.

\section{ABSTRACT}

Shared values are typically seen as one of the core aspects of culture. The usual procedure for deriving shared cultural values is through analyzing individuals' value priorities at the cultural-level. This paper outlines the conceptual and methodological problems associated with this procedure. Findings from selected empirical 
studies are presented to corroborate this critique. Alternative ways of measuring cultural values at the individual-level are presented and classified into a value taxonomy. Within this taxonomy past studies have so far focused on measuring values through importance ratings reflecting what individuals or social groups "desire". However, the argument is made that if cultural values are supposed to be shared they should reflect what is "desirable", i.e. what one "ought" to value or to strive for as a goal in life in a certain society. This constitutes a new approach for the measurement of cultural values. It is proposed that cultural values are measurable at the individual-level using the concept of morality. Suggestions are made how moral values could be operationalized referring to either the individual's moral values or those of a social group. The benefits of the value taxonomy for future research are eventually described.

\section{KEYWORDS}

Values; Culture; Morality; Measurement; Theory.

\section{INTRODUCTION}

Research in cross-cultural psychology has investigated culture by focusing mainly on cognitive systems comprising different concepts such as values, attitudes, and beliefs. Most of the research has dealt with the concept of values to understand culture (EARLEY, 2006; BOND et al., 2004). This is probably due to the common understanding in the field that values are "among the building blocks of culture" (HOFSTEDE, I980, p. 25). More recently, crosscultural researchers have raised doubts about the usefulness of the value concept (GELFAND; NISHII; RAVER, 2006). Empirical findings show mixed results with some studies supporting the explanatory power of values and other studies showing that values are not sufficient for understanding cultural differences (see GELFAND; NISHII; RAVER, 2006). Furthermore, there is growing scepticism at a theoretical level that the mere cognitive approach on culture, where cultural values are detached from the contextual processes such as social constraints and norms, is useful to understand culture (EARLEY; MOSAKOWSKI, 2002; GABRENYA, I999; MOGHADDAM; STUDER, I997). It is not surprising that some researchers have suggested abandoning the value concept and have turned to potentially more useful concepts such as social axioms or 'cultural intelligence' (e.g. LEUNG et al., 2002; EARLEY; ANG, 2003). 
The scepticism may be legitimate to the extent that most cross-cultural researchers define cultural values as a conception of "the desirable" (BRAITHWAITE; SCOTT, I99I), by describing them as "desirable transsituational goals" (SCHWARTZ, I994, p. 2I; see also KLUCKHOHN, I95I; FEATHER, I996), but surprisingly take a rather asocial or acultural stance when measuring values through personal importance ratings of individuals. This approach assesses values as "the desired" or in other words what people personally want in their lives. In contrast to that, values as "the desirable" target people's opinion of what they "ought" or "should" strive for, which is influenced by culture and implies social constraints and pressures imposed upon the individual (see also HOFSTEDE, I980; HIGGINS, 2006; KLUCKHOHN, I95I; LEWIN, I952). The purpose of this article is to highlight this distinction and to stress the importance of social constraints and normative pressures for the measurement and understanding of culture if culture is defined as shared values and beliefs. With the help of a value taxonomy, past research is classified regarding their focus of measurement. Within this taxonomy suggestions are made how it may be possible to measure values as "the desirable". Finally, the benefits of distinguishing these different kinds of values are discussed in regard to future research.

\section{DEFINITION OF CULTURE: THE ROLE AND FUNCTION OF "SHARED" VALUES}

While culture can be defined in many different ways (cf. KROEBER; KLUCKHOHN, I952; BALDWIN et al., 2006), there seems to be a minimal consensus - at least in the field of anthropology and psychology - that it is a phenomenon of a collective and it is shared among its members (KASHIMA, 2000; KUPER, I999; LEHMAN; CHIU; SCHALLER, 2004; ROHNER, I984). Yet, there seems to be no agreement of what exactly this "sharedness" means (ROHNER, I984). Some cross-cultural researchers have conceptualized it in terms of observable patterns of cognitive structures which are distinctive to social groups (e.g. HOFSTEDE, I980). These are concepts such as values and beliefs that are assumed to influence behaviour. This places culture inside the minds of individuals as members of a cultural group, like in Hofstede's definition of culture as "the collective programming of the mind" (HOFSTEDE, I980, p. I3). Other definitions of culture in cross-cultural psychology go beyond the structural view by including the functions of culture (e. g. MATSUMOTO, 2007). Functional definitions suggest that concepts such as cultural values exist for a reason or purpose. One of the most important functions of culture is possibly its "guidance function" (cf. BALDWIN et al., 2006, p. 38; cf. KLUCKHOHN; STRODTBECK, I96I): culture 
helps to organize collective life by providing solutions to problems of everyday activities. It guides individuals by reducing the number of available interpretations of an event or person and in this way it is giving order to the world. It is this sense of order that people transmit via cultural values to new cultural members, which can be employees in an organization, migrants in a host country, or growing children (BALDWIN et al, 2006; ROE; ESTER, I999). Individuals are constrained by culture in so far that to be accepted as group members, they need to conform to cultural standards, which reinforce learning and internalization of cultural values (see also TRIANDIS, I972). This kind of structural-functional understanding of culture has been widely adopted by current cross-cultural theorists (e.g. SCHWARTZ, I994, 2006; TRIANDIS, I994).

From this point of view, shared values serve a purpose in social groups or cultures. Shared values are general guidelines which regulate behaviour of its members so that collective life is organized and individuals interact more smoothly. New members are explicitly and implicitly taught what is appropriate or socially desirable. Thus, culture draws boundaries and limits the individual's freedom by creating external constraints on what is accepted or appropriate and what is not. In this way, cultural values refer to what is judged as right or wrong, i.e. they refer to issues of morality. In fact, it is difficult to "delineate where culture ends and morality begins as culture and morality share an intricate and intimate relationship" (MILLER, 200I, p. I5I). Yet, this close interrelationship between culture and morality has so far been neglected in quantitative research on cultural values. In the following section the usual approach in identifying cultural values is briefly outlined as well as the methodological and conceptual problems associated with it. Subsequently, selected empirical studies are presented to corroborate the raised concerns of neglecting morality in form of social constraints in cultural values research. Recent alternative approaches of measuring cultural values are introduced and classified in a value taxonomy. A possible solution for measuring the so far neglected moral component of cultural values at the individual-level is finally presented.

\section{PAST APPROACH IN IDENTIFYING CULTURAL VALUES}

\subsection{THE CULTURE-LEVEL ANALYSIS APPROACH}

Cross-cultural research on values is carried out on two different levels of analysis: the individual- and the cultural-level (SMITH; SCHWARTZ, I997). At 
the individual-level, values are conceptualized as motivational goals serving as guiding principles in individuals' lives (ROKEACH, I973; SCHWARTZ; BILSKY, I987, I990). The procedure consists usually in individuals from different countries responding to the same value survey and indicating which values are personally important to them. After establishing equivalence of the scale, structureoriented techniques, such as factor analysis or multidimensional scaling, can be employed to identify value dimensions that characterize individuals in their motivational goals. Schwartz (I992) for example found that values are ordered in a circular fashion with the consequence that if individuals place emphasis on one value type (e.g. hedonistic values), they are likely to deemphasize the opposite value type on the value circle (here traditional values). Yet, these value dimensions do not represent cultural values, but only personal values. To measure cultural values, the responses of individuals need to be taken a step further and analyzed at the cultural-level. Here, the scores of individuals within countries are averaged, meaning that the cultural-level dataset consists of countries as cases instead of individuals. These country scores can then be analyzed with structure-oriented techniques to identify cultural value dimensions. Schwartz (1992, 1994) for example found that a culture-level analysis of his cross-cultural data yields also a circular value structure. Only that this time the value dimensions characterize whole societies and are different in their content compared to the individual-level dimensions. Countries that emphasize one value type (e.g. egalitarianism) deemphasize the opposite value type in the value circle (here hierarchy). These values are seen as representing the socially shared ideas of what is desirable or good and right in a society (cf. SMITH; SCHWARTZ, I997). They characterize cultures and are therefore labelled "cultural values".

\subsection{CONCEPTUAL AND METHODOLOGICAL PROBLEMS}

As already indicated above, the concept of values is multifaceted in the sense that it can describe not only individuals, but also cultural groups. Yet, since Hofstede (I980) it is common knowledge that what applies to cultural groups does not necessarily apply in the same way to individuals. Hofstede (i980) found that his country-level dimensions, such as collectivism and individualism, could not be replicated at the individual-level. Since then the two levels of analysis are neatly separated and applying country-level dimensions to individuals is seen as committing the "ecological fallacy" (cf. HOFSTEDE, I980, p. 28-3I). The consequence of this fallacy problem is that in a strict sense one cannot compare individuals in terms of cultural value dimensions such as individualism and collectivism. This is a characteristic that applies only to countries, cultures or other social entities. From a psychological perspective, the ecological fallacy remains a puzzling and 
less well-understood phenomenon until today (SMITH; SCHWARTZ, I997). After all, the country-level dimensions are derived from individuals' responses. Yet, statistically aggregating their responses at the country-level renders them inapplicable to individuals. Another puzzling issue is that, only the culture-level approach is seen as measuring culture in the sense of what is socially shared and the abstract ideas of what is good, right, appropriate and desirable in a cultural group (HOFSTEDE, I980; SCHWARTZ, I994; SMITH; SCHWARTZ, I997). An inevitable conclusion is that if we want to study cultural values, we need to "limit" ourselves to country-level analyses. However, there are several objections to this inference.

The first objection is epistemological in nature referring to the assumption that only country-level dimensions reflect shared cultural values. In country-level analyses, culture is treated as the sum of all sampled individuals from a specific cultural group. That means that culture is seen as only measurable when the responses of individuals within a cultural group are aggregated. This may be adequate for sociological endeavours, also reflected by the usual procedure of validating country-level dimensions with sociological indices such as gross domestic product (e.g. HOFSTEDE, I980). However, from a psychological perspective of culture, with the aim to understand human behaviour, it seems more relevant to try to comprehend each human being as an expression of culture (BRUNER, I990) and thus to investigate the manifestation of cultural values at the individual-level relying on intrapsychic cognitive structures of individuals. A possible way of doing this could be by including morality as a concept in the measurement of values to capture external normative pressures in a society. This will be discussed in more detail below.

A further objection concerns the way cultural values are operationalized. Most of the value surveys measure the personal importance of values (e.g. Chinese Value Survey (CHINESE CULTURE CONNECTION, I987), Rokeach Value Survey (ROKEACH, I973) and Schwartz Value Survey (SCHWARTZ, I992)). The Schwartz Value Survey (SVS) (SCHWARTZ, I992) for example requires individuals to indicate "What values are important to ME as guiding principles in MY life?". From a social psychological point of view, the statistical average of personal value priorities does not tell us what kind of social constraints or normative pressures are prevalent in a certain culture. It does not answer questions such as: What are we supposed to value or strive for? Or what kind of behaviour are we supposed to adopt in different cultures? Averaging personal value priorities reflects merely what a majority deems as important in a culture and can be called "actual rather than ideal cultural value priorities" (SCHWARTZ, I992, p. 5I). The problem is that operationalizing values with personal importance ratings conflates two different motives of valuing: values may be seen as personally important 
because (I) they are well internalized socially desirable values, or (2) they have an intrinsically positive quality which leads to a hedonic experience of appraisal when the value is fulfilled (see also HIGGINS, 2006; FEATHER, I999). For instance the value "pleasure" from the SVS may be judged as important because of this very hedonic motive and not because it is a socially desirable standard. Values as "the desirable" go beyond the evaluation of whether a value is just pleasant or unpleasant for oneself by implying judgments of what is desirable or morally right or wrong. The usual procedure of averaging personal values and deriving cultural values from that neglects these kinds of social constraints and expectations that culture imposes upon individuals.

The last objection deals with the methodological consequences. Sticking to the culture-level approach to identify cultural values restricts future research in a practical sense: either we limit ourselves to cultural value dimensions that have already been identified, for example the seven culture-level value types by Schwartz (I994), or every researcher who suggests potentially new and meaningful values (e.g. "protestant ethic values" (VERKASALO et al., 2008)) needs to conduct an extensive cross-cultural study to be able to claim that they are valid cultural values. This would mean sampling of individuals from at least 50 countries to ensure that the new country-level value dimension is stable (cf. FISCHER et al., 2008). It would also mean conducting a very costly, effort-and time-intensive research project (NORENZAYAN; HEINE, 2005).

\subsection{EMPIRICAL EVIDENCE UNDERPINNING THE PROBLEMS}

One may wonder whether personal and cultural values are indeed different. Or whether it would really make a difference if cultural values were not derived from a culture-level analysis, but measured at an individual-level and differently from personal values. Would it really add something to our understanding? There is indirect empirical evidence that it would. It seems indeed that personal importance ratings of values do not capture the normative aspect of values prevalent in social groups.

As Fischer (2008) pointed out, if culture is defined in terms of shared values, any measure of cultural values should show that individuals from the same culture endorse similar values, and that cross-national variation exceeds indeed intranational variability. Cross-cultural data from the Schwartz Value Survey study (SCHWARTZ, I992, p. 50) analyzed at the individual-level revealed that there is "substantial individual variance in response to every single value" instead of consensus which would have been an indicator for shared cultural values. Furthermore, this individual variance does not seem to reflect measurement error as it was systematically associated with individual differences in participants' 
background characteristics, their attitudes or behaviour. Schwartz (I992, p. 5I) eventually concludes that his survey is measuring personal values and that "one cannot derive the normative ideals of a culture from the average of individual responses".

Furthermore, it seems that personal values can even be compromised when the normative pressure is high. Bardi and Schwartz (2003) conducted a study to investigate the value-behaviour link at the individual-level. They assessed values with the SVS (SCHWARTZ, I992) and sampled behavioural items supposed to represent the values. Their results showed that the more frequent a behaviour was reported, the less consistently values were associated with the behaviour. In other words, if everybody seems to behave in a certain way or if a certain behaviour is the norm in a social group, people report to behave the same way even if it is not congruent with their personal values. Only when external pressure is absent, the personal importance of values may influence their behaviour. Since from a functional perspective culture can be seen as creating external constraints and putting normative pressures on the individual, Bardi and Schwartz' study underpins the here proposed argument that personal importance ratings may not reflect the "shared" ideas in a social group what one should do or should strive for. And from a conceptual perspective this does not change if the data is analyzed at a statistically higher level.

Another area of research in which the conceptual and empirical distinction of personal values and those of the social context may play an important role, is in the area of value fit between individual and social group as well as value change. Rohan and Maiden's (2000) used a modified form of the SVS to measure value priorities of teachers and what they call the "ideological" value system of their schools which is the teachers' perception of the school's value priorities. They showed that the fit between teachers' personal values and their perception of the school's values strongly predicted reported stress, job commitment, and satisfaction. As Rohan and Maiden (2000) state, this prediction could not have been obtained by merely constructing an index of fit based on teachers' personal values and the aggregated value priorities of all teachers in the respective schools. The fundamental issue lies in the fact that aggregated personal values of individuals do not contain much social psychological information.

If value change is investigated, the importance and benefit of operationalizing values of the social environment and of the individual differently becomes even more obvious. There is the problem of causal inconsistency if cultural values are represented by mere aggregation of individuals' personal values. As Roe and Ester (I999, p. 4) highlight: "It is hard to assume that a change in cultural values causes a change in individual values if the change in cultural values is operationally defined as the sum of individual changes". These empirical studies 
suggest that personal value priorities (I) do not contain information about values that are socially desirable, and (2) impede a deeper social psychological understanding if they are not operationalized separately for the micro-and macro-level. The following section proposes how values can be operationalized at these two conceptually (not analytically) different levels while remaining at the individuallevel of analysis.

\section{ALtERNATIVE WAYS OF MEASURING CULTURAL VALUES BY STICKING TO THE INDIVIDUAL-LEVEL OF ANALYSIS}

\section{RECENT APPROACHES: CHANGING THE FRAME OF REFERENCE}

Recent studies have adopted the approach to measure cultural values by changing the frame of reference from self to others. Here individuals are asked about their perception of other people's values (FISCHER, 2006; WAN et al., 2007). Wan et al. (2007) underlying assumption is that cultural values are those that are strongly endorsed by most members of the culture. Instead of just averaging the value priorities of a social group, they argue that it is more appropriate to let research participants estimate how an average member of a cultural group would respond to the value survey as culture resides in its members' intersubjectivity. Consequently, a value has high intersubjective importance when most of the research participants agree that an average member of their group would strongly endorse the value. Wan et al used the Schwartz Value Survey (SVS) and measured personal values of Chinese university students. They also asked the participants in a modified version of the SVS to rate the importance of the values to "an average student at the university" (WAN et al., 2007, p. 2I7) and to an average person of their cultural group. They called this measurement strategy "intersubjective consensus approach" or 'perceived cultural importance' approach alternatively (WAN et al., 2007). They used this approach to identify those cultural values that differentiate between Chinese, Singaporean and university culture. Their findings show a general tendency that the more personally important "culturally" distinctive values were rated, the more respondents identified with the respective cultural groups suggesting that personal values may reflect cultural identity and thus cultural values. However, as the authors note this relationship did not hold for all cultural identifications, but only for those referring to subcultures, for instance the identification with the university culture. The reason may 
be that it is difficult for respondents to rate the value importance of an average person belonging to a greater cultural entity such as national culture.

Fischer's (2006) solution for measuring cultural values also consisted in changing the frame of reference. The Schwartz Value Survey was taken for this purpose and modified by instructing respondents from ten different countries to rate the importance of each value for most of the people in their country of birth. He analyzed the data at the culture-level and correlated them with Schwartz' culture-level data on self-referenced ratings of values. The results illustrate that selfand culture-referenced ratings do not show great overlap, sharing only $7.84 \%$ of their variance. Only values of the cultural value dimensions embeddedness (feeling attached and socially connected to social groups) and affective autonomy (pursuing affectively positive experiences for oneself) were related to self-referenced ratings. Fischer concludes that researchers need to be careful about interpreting aggregated self-reports in terms of cultural values and that there is more research needed that investigates the normative aspects of culture to understand the functions and processes of culture. These value studies have contributed to an advancement in cross-cultural value research by considering different references when using self-reported ratings of individuals. To provide a better overview, a value taxonomy is presented where these studies can be classified.

\subsection{CLASSIFYING VALUE RESEARCH AT THE INDIVIDUAL- LEVEL: PROPOSING A VALUE TAXONOMY}

Box I shows how past research investigating values at the individual-level may be classified. There are two dichotomous features of values: they can either refer to the individual or collective and to "the desired" (what and individual wants as a goal in life) or 'the desirable' (what an individual ought to want as a goal in life). This yields a $2 \mathrm{X} 2$ classification of four different value types. Personal values refer to the individual and what they desire for themselves which has for example been studied by Schwartz (1992). Studies that change the frame of reference to value importance ratings of a social group measure conceptually also what is desired (cf. FISCHER, 2006; WAN et al., 2007). However, here it does not apply to an individual, but to a whole social group. These kinds of values may be labelled "social values". The term does not refer to the content of values, for instance prosocial, desirable or moral values, but to the holder of these values, which is a social entity. In order to assess the normative component of values in the sense of what one should or ought to strive for, values need to be measured as the desirable. Possible solutions to achieve this are proposed next. 


\section{Box I}

VALUE TAXONOMY: THE MEASUREMENT

OF VALUES AT THE INDIVIDUAL-LEVEL

\begin{tabular}{lll}
\hline & \multicolumn{1}{c}{ INDIVIDUAL } & \multicolumn{1}{c}{ COLLECTIVE } \\
\hline Desired (wanting) & Personal Values & Social Values \\
& $\begin{array}{l}\text { Operationalization: Important to } \\
\text { me/you }\end{array}$ & $\begin{array}{l}\text { Operationalization: Important to } \\
\text { people in my culture }\end{array}$ \\
\hline Desirable (ought) & $\begin{array}{l}\text { Personal Moral Values } \\
\text { (personally desirable) }\end{array}$ & $\begin{array}{l}\text { Social Moral Values } \\
\text { (socially desirable) }\end{array}$ \\
& $\begin{array}{l}\text { Operationalization: What one } \\
\text { ought to strive for; right vs. } \\
\text { wrong; feeling of guilt if value } \\
\text { violated }\end{array}$ & $\begin{array}{l}\text { Operationalization: What one } \\
\text { is expected to strive for in the } \\
\text { respective society/culture }\end{array}$ \\
\hline
\end{tabular}

Source: Elaborated by author.

\subsection{PROPOSAL FOR A NEW APPROACH: INCORPORATING MORALITY IN THE MEASUREMENT OF VALUES}

The difference between the "the desired" and "the desirable". While studies described above measure what is desired, cultural values may be better operationalized if measured as "the desirable". Values as "the desired" refer to what individuals intrinsically "want" to strive for or what they personally desire in their life (e.g. BRAITHWAITE; SCOTT, I99I). Value instruments that measure "the desired" address individuals by instructing to ask themselves for example what values are important to them as guiding principles in their life (e.g. SCHWARTZ, I992, p. 50). In contrast to that, values as "the desirable" refer to what individuals "ought" to strive for or what they should desire (DEWEY, I939) which in regard to culture is something that has been extrinsically imposed upon them. An alternative way of conceptualizing the difference between "the desirable" and "the desired" is by assigning values "direction and intensity" (HOFSTEDE, I980, p. 20; see also HIGGINS, 2006; KLUCKHOHN, I95I; LEWIN, I952). "The desirable" represents the directional component of values and has an evaluative meaning in the sense that individuals judge whether a certain value is right or wrong to strive for (cf. KLUCKHOHN, Ig66). "The desired" on the other hand refers to the strength or intensity of a value. Thus, holding a value means not only that 
this value is relevant or important to a certain degree (intensity), but at the same time it can also be evaluated in a sense of whether it is right or wrong to strive for it (direction). Thus, values as "the desired" and "the desirable" relate to values of two different natures. According to Hofstede (I980) this has implications for the interpretation of their norms. Taking the statistical average of values as "the desired" indicates to what extent the majority endorses the values. This is an approach which has been mostly adopted in cross-cultural value research (e.g. CHINESE CULTURE CONNECTION, I989; SCHWARTZ, I994). In the case of "the desirable", the assessed values contain implicitly an ideological norm in the sense of what is seen as morally² right or wrong (cf. HOFSTEDE, I980; KLUCKHOHN, I95I). Hofstede (I980) provides a plausible example as an illustration of the difference between "the desired" and "the desirable": An individual may "desire" "wealth" as a value or "having money" and consider it as highly relevant (intensity) in the sense that one needs some of it to lead a decent life. Thus, "wealth" is seen as something important and its fulfilment may lead to a positive intrinsic feeling such as satisfaction. However, the same person, especially if adhering to Christian principles, could judge this value as wrong in the sense of adopting it as "a guiding principle in life".

Yet, how can "the desirable" component of values be measured? This is discussed next with regard to whether values refer to what an individual deems as desirable (internalized moral values) or to what a social group judges as desirable.

\subsubsection{Socially moral values: "the desirable" and the collective}

Similar to the operationalization of "the desired" for a collective, the choice of reference may be that individuals are asked about other people in their culture and what kind of values others may regard as right to strive for. Values have been described as possessing a bipolar valence (e.g. FISHBEIN; AJZEN, I975; ROKEACH, I973). Thus, a possible way of measuring desirable values is to ask individuals whether other people in their society would judge certain values right or good as opposed to wrong and bad (see also HOFSTEDE, I980). The evaluation factor of the semantic differential developed by Osgood, Suci and Tannenbaum (1957) may be very useful for this purpose. Osgood, Suci and Tannenbaum (I957) found in an extensive cross-cultural study in more than

Hofstede (I980, p. 2I) does not use the term moral, but says that the ideological norm is "pertaining to what is ethically right". I use the term ethics and its derivations only to refer to philosophy as the science of ethical reasoning. When it is about people's everyday judgments of right and wrong, I assign it to the realm of morality. 
20 cultural groups that three distinctive factors emerge when bipolar adjectives are taken to assess different concepts: evaluation (e.g. good-bad), potency (e.g. strong-weak) and activity (e.g. active-passive). The evaluative valence of values may be examined to find out which values are desirable or judged as right to strive for in a society. However, if questions are referred to other people, there is always the possibility that respondents simply do not know or are not aware of the values that others deem as desirable (see also WAN et al., 2007). Another problem is that individuals may infer from their own values to those of others and regard them as normative, known as the false consensus effect in the social psychological literature (for a review see MARKS; MILLER, I987). A solution may be to rely on intrapsychic cognitive structures which are based on individuals' own experience. This could be done for instance by asking what kind of social expectations individuals experience in a particular society or social group. A possible question to measure socially desirable values may be for instance "to what extent do you think you are expected (or supposed) to follow this value in your society/culture etc.?". Since internalization of cultural values is likely to be a lifelong process (cf. ALLPORT, I955) where individuals try to reconcile social constraints with their personal desires (see also DECI; RYAN, I995; ROHAN; ZANNA, I998; ZAVALLONI, I980), the kind of social expectations that are imposed upon them may be psychologically very well accessible. To the best of the author's knowledge, there are no cross-cultural studies measuring this aspect of values. Thus, there is a great potential for future research to measure cultural values using this alternative method ${ }^{3}$.

\subsubsection{Personal moral values: "the desirable" and the individual}

Assessing what is desirable for an individual gives moral values another spin. What is important here is that values are not only imposed, but are also internalized by the individual to a certain degree (cf. RYAN; DECI, 2000). How can these kinds of values be measured? One could again use a bipolar evaluative response scale of "good vs. bad" or "right vs. wrong" (cf. OSGOOD; SUCI; TANNENBAUM, I957), but this time the choice of reference would be the individual in the sense of what she/he regards as right or wrong to strive for in life. The average of respondents' answers represents then not only a statistical norm but also a deontological one (pertaining to what one ought to strive for). Following this procedure, a researcher may be able to ask simultaneously for

We are currently conducting a cross-cultural study using a modified form of the SVS where the response scales represent bipolar statements measuring "the desired" and "the desirable" nature of values. A copy of this measure can be obtained from the author. 
each value the personal importance (important-unimportant) and its evaluative meaning. Thus, it would be possible to examine the congruence between what people "want" to strive for in life and what they think they "should want" to strive for as a guiding principle in life. The drawback of this method could be that individuals may not assign "deeper" meaning to the evaluative scale and rate what is "important" and what is "right" in the same way, possibly as an attempt to reduce cognitive dissonance (FESTINGER, I957). Another possibility of measuring "the desirable", which may be more reliable as it is less subjected to response styles, is to ask for moral emotions such as the feeling of guilt when violating a value. Moral emotions are in general seen as an important motivational factor to do good and avoid doing bad (BEDFORD; HWANG, 2003; TANGNEY, 2002). It is the self-conscious emotion of guilt that plays a major role in morality (cf. AMODIO; DEVINE; HARMON-JONES, 2007; BAUMEISTER; STILLWELL; HEATHERTON, I994; EISENBERG, 2000; HAIDT, 2003). Guilt is widely recognized as an important self-punishing emotion for action evaluation and regulation (FONTAINE et al., 2002). It is a negative affective experience that is evoked when one's behaviour falls short of either personal moral or societal standards (AMODIO; DEVINE; HARMON-JONES et al., 2007). Shame is also a moral emotion, but associated with a rather egocentric concern for one's self-image. Guilt is more an allocentric concern for the consequences of one's behaviour on other people (BEDFORD; HWANG, 2003; TANGNEY, 2002). As a consequence, moral transgressions have generally been considered more linked to guilt than to shame (BEDFORD; HWANG, 2003). Thus, asking for guilt feelings when violating a value and examining its statistical average may be a good indicator for shared desirable and therefore cultural values that have been internalized.

\section{BENEFITS OF DISTINGUISHING DIFFERENT MEASUREMENTS OF VALUES}

\subsection{PERSONALLY DESIRED VERSUS PERSONALLY DESIRABLE}

The value taxonomy classifies value research into the dichotomous dimension of measuring 'the desired' aspect of values (through importance ratings) or the evaluative component of values in form of what is "desirable". Furthermore, it distinguishes whether values refer to the individual or a collective. Crossing these dimensions yield for example that values can be classified as "personally 
desired" and "personally desirable". It may not be obvious to see the difference between these two kinds of values. This section deals with their fundamental distinction and how it may relate to the prediction of behaviour.

The problem with measuring values as "the desired" through importance ratings is that there is a great deal of ambiguity regarding their underlying meaning. Values that individuals judge as important may have two different motivational sources: The first one is extrinsic in nature. Important values may be those that were initially extrinsic and have been imposed upon the individual by the social environment. Through socialization processes, the individual may have integrated it as part of the self, so that they become personally important (cf. RYAN; DECI, 2000). The second motivational source is completely different representing an intrinsic kind of motive. Here, individuals may judge values as important, because fulfilling them leads to enjoyment or inherent satisfaction (see also WAN et al., 2007; RYAN; DECI, 2000). The problem is that assessing the personal importance of values does not allow distinguishing between these two different sources of motivation. As already outline above in which the Bardi and Schwartz (2003) study has been referred to, it seems that this is not a trivial distinction. They showed that personal values- which conflate the intrinsic and extrinsic dimensions of values- were not related to behaviour when the normative pressure of the behaviour was high. It is possible that the value-behaviour link is more stable if not personally desired values are measured, but personally desirable values as they may provide an internal moral compass of "oughts" and "shoulds".

Research on moral mandates may corroborate this assumption showing that personal moral values have a high action potential (SKITKA, 2002; SKITKA; HOUSTON, 200I; SKITKA; MULLEN, 2002). Skitka and colleagues showed that the value-behaviour link is especially strong for individuals with moral mandates which are selective expressions of values and central to people's sense of personal identity. Moral mandates are characterized by attitude strength, importance, and certainty, but include the additional layer of moral conviction, i.e. a strong belief that an issue is right or wrong. People who develop moral mandates are highly motivated to express and protect them. Skitka and Mullen's (2002) examined reactions of US-American adults to the Elian Gonzales case who became the centre of a heated public controversy and custody battle between his father in Cuba and his extended family in the USA. People in both the USA and Cuba engaged in demonstrations to defend their divergent position and values on the same issue. Thus, it seems that moral mandates are a common phenomenon. Yet, the content of moral mandates may be culturally influenced. Skitka and colleagues research can be interpreted in the way that personally desirable values 
may yield stronger links between values and behaviour. Hence, the reputation of values as being only distally related to behaviour may be eventually refuted when assessing values as the "personally desirable" (cf. HITLIN; PILIAVIN, 2004).

\subsection{INDIVIDUAL VERSUS COLLECTIVE - WHEN IS CULTURE MEASURED?}

Values may refer to the individual or a social entity. Socially desirable values as depicted in Box I have been discussed as measuring the values of the social environment such as the cultural group. Yet, personally desirable values may also be used to measure cultural values. If individuals are for example asked whether they would feel guilty after violating values, a high statistical average on certain values may indicate that these are the internalized shared values in the respective culture. Thus, both procedures may lead to the assessment of cultural values. However, they are fundamentally different in two ways: First, socially desirable values measure only the perceived values of a social group. This is adequate if operationalizing the cultural context for example is the focus of the study. Yet, it does not provide any information whether the respondents adhere to these values. Whether these values have been internalized or not may be important to assess in studies that focus on the relation of values to other variables, such as behaviour. As it has been outlined above, there may be a strong value-behaviour link if individuals' personal moral values are assessed.

Secondly, if the focus of a study is on examining individual differences in personal moral values, assessing the perceived values of the social environment is inadequate. The intriguing feature of moral values and the process of internalization is that they can stem from different sources located on a continuum of more proximal sources such as caregivers and peers to more distant sources such as teachers, media and society. Therefore, internalized moral values may potentially reflect those of a culture. However, especially when it comes to strong political ideologies, it is also possible that individuals develop different internalized values, provided by their caregivers for example, than those that are perceived as prevalent in the wider society and in the political propaganda. Prominent examples are the German siblings Sophie and Hans Scholl who during the third Reich in Germany opposed actively the national socialist regime and their supporters. They strongly supported the humanist values of their father. They regarded these values as the morally right ones and fought for it, taking into account that they may be and finally were sacrificing their own lives. The proposed value taxonomy takes this important aspect of moral values into account, i.e. the individual differences in moral value endorsement despite the normative pressures. 


\section{CONCLUSION AND FINAL REMARKS}

There has been a lot of definitional inconsistency in values-related theory and research (ROHAN, 2000). Values have been used to refer to other psychological constructs such as attitudes, beliefs, norms, and behavioural self-reports (cf. HITLIN; PILIAVIN, 2004) as well as interests, pleasures, likes, preferences, duties, moral obligations, desires, wants, goals, needs, and many other kinds of selective orientations (see ROHAN, 2000). However, if values as "the desirable" are the target concept to understand culture, it is important not to confound them with other related concepts. Each type of concept may play a distinctive role in explaining and understanding behaviour. This is why a value taxonomy has been proposed to clearly distinguish between individual and collective values as well as "the desired" and "the desirable". While "the desired" may be associated with a purely intrinsic motivation to pursue values, "the desirable" contains also social psychological processes, such as the internalization of extrinsic demands and behavioural regulation. Regarding the latter feature, moral psychology can help a great deal to understand and examine the social constraints and normative pressures prevalent in different cultures.

While some researchers argue to abandon the value concept, values are here seen as a useful concept to understand culture. The dissatisfaction with the value concept may rather be associated with the fact that value research has still not come to its full potential. Hopefully, the value taxonomy may inspire researchers to operationalize cultural values beyond mere importance ratings. As De Munck (200I, p. I4) states: "collective constructs, [must] be easily learned, acquired from everyday life experiences, abstract and flexible enough to be used for a wide range of situations". Cultural values fulfil this task and have a number of other advantages. They are highly suitable for cross-cultural research as they are cross-culturally relevant and valid and allow for both within- and betweengroup comparison (HILLS, 2002). They are trans-situational guidelines and in this sense not tied to specific situations making it easier to assure cross-cultural equivalence for comparisons. The total number of values that people may pursue is assumed to be relatively small (ROKEACH, I973) which reduces their complexity in research. They are also less subjected to change as it is the case with attitudes (HILLS, 2002). Last not least, they may be essential in understanding the underlying motives of social norms, which are behavioural descriptions in specific situations (ROKEACH, I973).

In this account, the Schwartz Value Survey has been referred to several times which can be understood as an indication of its popularity to measure explicit value priorities. Recent research has also been presented where the instruction 
of the survey has been modified to measure cultural values at the individuallevel. The SVS is an excellent instrument to measure values and can be easily modified in its response scale to capture the different value types as proposed in the value taxonomy. Thus, the SVS provides a sound foundation for exploring and extending value research to enrich our understanding of cultural values.

\section{REFERENCES}

ADAMOPOULOS, J. On the entanglement of culture and individual behavior. In: VAN DE VIJVER, F. J. R.; VAN HEMERT, D. A.; POORTINGA, Y. H. (Ed.). Individuals and cultures in multi-level analysis. Mahwah, NJ: Lawrence Erlbaum Associates, 2008. p. 27-62.

ALLPORT, G. W. Becoming: basic considerations for a psychology of personality. New Haven, CT: Yale University Press, I955.

AMODIO, D. M.; DEVINE, P. G.; HARMON-JONES, E. A dynamic model of guilt: implications for motivation and self-regulation in the context of prejudice. Psychological Science, v. I8, p. 524-530, 2007.

BALDWIN, J. R. et al. Redefining culture: perspectives across the disciplines. Mahwah, NJ: Lawrence Erlbaum Associates Publishers, 2006.

BARDI, A.; SCHWARTZ, S. H. Values and behavior: strength and structure of relations. Personality and Social Psychology Bulletin, v. 29, p. 1207-1220, 2003.

BARDI, A.; CALOGERO, R. M.; MULLEN, B. A new archival approach to the study of values and value-behavior relations: validation of the value lexicon. Journal of Applied Psychology, v. 93, p. 483497, 2008.

BAUMEISTER, R. F.; STILLWELL, A. M.; HEATHERTON, T. F. Guilt: an interpersonal approach. Psychological Bulletin, v. II5, p. 243-267, I994.

BEDFORD, O.; HWANG, K. K. Guilt and shame in Chinese culture: a cross-cultural framework from the perspective of morality and identity. Journal for the Theory of Social Behaviour, v. 33, p. I27-I44, 2003.

BERRY, J. W. Conceptual approaches to acculturation. In: CHUN, K. M.; ORGANISTA, P. B.; MARÍN, G. (Ed.). Acculturation: advances in theory, measurement and applied research. Washington, DC: American Psychological Assoc, 2003. p. I7-37.

BLASI, A. Bridging moral cognition and moral action: a critical review of the literature. Psychological Bulletin, v. 88, p. I-45, I980.

BOND, M. H. Adding value to the cross-cultural study of organizational behavior. In: EARLEY, P. C.; EREZ, M. (Ed.). New perspectives in international industrial/organizational psychology. San Francisco: New Lexington Press, I997. p. 256-275.

BOND, M. H. et al. Culture-level dimensions of social axioms and their correlates across 4I cultures. Journal of Cross-Cultural Psychology, v. 35, p. 548-570, 2004.

BRAITHWAITE, V. A.; SCOTT, W. A. Values. In: ROBINSON, J. P.; SHAVER, P. R.; WRIGHTSMAN, L. S. (Ed.). Measures of personality and social psychological attitudes. San Diego, California: Academic Press, I99I. v. I, p. 66I-753. 
BREWER, M. B.; CHEN, Y. R. Where (who) are collectives in collectivism? Toward conceptual clarification of individualism and collectivism. Psychological Review, v. II4, p. I33-I5I, 2007.

BRUNER, J. S. Acts of meaning. Cambridge, MA: Harvard University Press, I990.

CHINESE CULTURE CONNECTION. Chinese Values and the Search for Culture-Free Dimensions of Culture: The Chinese Culture Connection. Journal of Cross-Cultural Psychology, v. I8, p. I43-I64, I987.

DECI, E. L.; RYAN, R. M. Human autonomy: The basis for true self-esteem. In: KERNIS, M. H. (Ed.). Efficacy, agency, and self-esteem. New York: Plenum, I985. p. 3I-49.

DE MUNCK, V. C. In the belly of the beast: two incomplete theories of culture and why they dominate the social sciences (part 2). Cross-Cultural Psychology Bulletin, v. 35, p. 5-I7, 200 I.

DEWEY, J. The theory of valuation. Chicago: University of Chicago Press, I939.

EARLEY, P. C. Leading cultural research in the future: a matter of paradigms and taste. Journal of International Business Studies, v. 37, p. 922-931, 2006.

EARLEY, P. C.; ANG, S. Cultural intelligence: individual interactions across cultures. Palo Alto, CA: Stanford University Press, 2003.

EARLEY, P. C.; MOSAKOWSKI, E. Linking culture and behavior in organizations: suggestions for theory development and research methodology. In: DANSEREAU F.; YAMMARINO, F. J. (Ed.). Research in multi-level issues. San Francisco: Elsevier Science, 2002. v. I, p. 279-319.

EISENBERG, N. Emotion, regulation and moral development. Annual Review of Psychology, v. 5I, p. 665-697, 2000.

FEATHER, N. T. Assimilation of values in migrant groups. In ROKEACH, M. (Ed.). Understanding human values: individual and societal. New York: The Free Press, I979. p. 97-I28.

FEATHER, N. T. Values, valences, and choice: the influence of values on the perceived attractiveness and choice of alternatives. Journal of Personality and Social Psychology, v. 68, p. II35-II5I, I995.

Values, deservingness, and attitudes toward high achievers: research on tall poppies. In: SELIGMAN, C.; OLSON, J. M.; ZANNA, M. P. (Ed.). The Ontario symposium: the psychology of values. Mahwah, NJ: Lawrence Erlbaum Associates, I996. v. I8, p. 215-25I.

Values, achievement, and justice: studies in the psychology of deservingness. New York: Kluwer Academic; Plenum Publishers, I999.

FESTINGER, L. A theory of cognitive dissonance. Stanford, CA: Stanford University Press, I957.

FISCHER, R. Congruence and functions of personal and cultural values: do my values reflect my culture's values? Personality and Social Psychology Bulletin, v. 32, p. I4I9-I43I, 2006.

Multilevel approaches in organizational settings: opportunities, challenges and implications for cross-cultural research. In: VIJVER, F. J. R. van de; HEMERT, D. A. van; POORTINGA, Y. (Ed.). Individuals and cultures in multi-level analysis. Mahwah, NJ: Lawrence Erlbaum Associates, 2008. p. I73-I96.

FISCHER, R.; SMITH, P. B. Justice criteria in the work place: the importance of values for perceptions of justice. Applied Psychology: International Review, v. 55, p. 54I-562, 2006.

FISCHER, R. et al. Are individual - and culture-level value structures different? Testing Hofstede's legacy with Schwartz' data. Unpublished manuscript, 2008.

FISHBEIN, M.; AJZEN, I. Belief, attitude, intention, and behavior: an introduction to theory and research. Reading, Mass.: Addison-Wesley Pub. I975. 
FONTAINE, J. R. J. et al. Cognitive structure of emotion terms in Indonesia and the Netherlands. Cognition and Emotion, v. I6, p. 6I-86, 2002.

FORSYTH, D. R. A taxonomy of ethical ideologies. Journal of Personality and Social Psychology, v. 39, p. I75-I84, I980.

FORSYTH, D. R.; NYE, J. L. Personal moral philosophies and moral choice. Journal of Research in Personality, v. 24, p. 398-4I4, I990.

GABRENYA, W. Psychological anthropology and the "levels of analysis" problem: we married the wrong cousins. In: LASRY, J. C.; ADAIR, J.; DION, K. (Ed.). Latest contributions to cross-cultural psychology. Lisse, the Netherlands: Swets \& Zeitlinger, I999. p. 333-35I.

GELFAND, M. J.; NISHII, L. H.; RAVER, J. L. On the nature and importance of cultural tightnesslooseness. Journal of Applied Psychology, v. 9I, p. I225-I244, 2006.

GILLIGAN, C. In a different voice: psychological theory and women's development. Cambridge, MA, US: Harvard University Press, I982.

HAIDT, J. The moral emotions. In: DAVIDSON, R. J.; SCHERER, K. R.; GOLDSMITH, H. H. (Eds.). Handbook of affective sciences. Oxford: Oxford University Press, 2003.

HIGGINS, E. T. Value from hedonic experience and engagement. Psychological Review, v. II3, p. 439460, 2006.

HILLS, M. D. Kluckhohn and Strodtbeck's values orientation theory. In: LONNER, W. J. et al. (Ed.). Online readings in psychology and culture. Bellingham, Washington: Center for Cross-Cultural Research, Western Washington University, 2002.

HITLIN, S.; PILIAVIN, J. A. Values: reviving a Dormant concept. Annual Review of Sociology, p. 359-393, 2004 .

HOFSTEDE, G. Culture's consequences: international differences in work-related values. Beverly Hills: Sage, I980.

HOFSTEDE, G.; BOND, M. H. Hofstede's culture dimensions: an independent validation using Rokeach's Value Survey. Journal of Cross-Cultural Psychology, v. I5, p. 4I7-433, I984.

INGHILLERI, P. From subjective experience to cultural change. Translation E. Bartoli. New York: Cambridge University Press, I999.

KAGITÇIBAȘI, Ç. Autonomy and relatedness in cultural context: implications for self and family. Journal of Cross-Cultural Psychology, v. 36, p. 403-422, 2005.

KASHIMA, Y. Conceptions of culture and person for psychology. Journal of Cross-Cultural Psychology, v. 3I, p. I4-32, 2000.

KLUCKHOHN, C. Values and value-orientations in the theory of action: an exploration in definition and classification. In: PARSONS, T.; SHILS, E. (Ed.). Toward a general theory of action. Cambridge, MA: Harvard University Press, I95I. p. 388-433.

Introduction. In: LESSA, W. A.; VOGT, E. Z. (Ed.). Reader in comparative religion: an anthropological approach. 2. ed. New York: Harper \& Row, I966.

KLUCKHOHN, F. R.; STRODTBECK, F. L. Variations in value orientations. Evanston, Ill: Row, Peterson, I96I.

KOHLBERG, L. Stage and sequence: the cognitive-developmental approach to socialization. In: GOSLIN, D. A. (Ed.). Handbook of socialization theory and research. Chicago: Rand Mc-Nally, I969. KOZAN, M. K.; ERGIN, C. The influence of intra-cultural value differences on conflict management practices. International Journal of Conflict Management, v. Io, p. 249-267, I999. 
KROEBER, A. L.; KLUCKHOHN, C. Culture: a critical review of concepts and definitions. Cambridge, Mass.: Peabody Museum of American Archaeology and Ethnology; Harvard University, I952. KUPER, A. Culture: the anthropologists' account. London: Harvard University Press, I999. LEHMAN, D. R.; CHIU, C. Y.; SCHALLER, M. Psychology and culture. Annual Review of Psychology, v. 55 , p. 689-714, 2004 .

LEUNG, K. et al. Social axioms: the search for universal dimensions of general beliefs about how the world functions. Journal of Cross-Cultural Psychology, v. 33, p. 286-302, 2002.

LEWIN, K. Constructs in field theory. In: Cartwright, D. (Ed.). Field theory in social science: selected theoretical papers by Kurt Lewin. London: Tavistock, I952. p. 30-42.

MARKS, G.; MILLER, N. Ten years of research on the false-consensus effect: An empirical and theoretical review. Psychological Bulletin, v. I02, n. I, p. 72-90, Jul. I987.

MATSUMOTO, D. The discrepancy between consensual-level culture and individual-level culture. Culture \& Psychology, v. 9, p. 89-95, 2003.

Culture, context, and behavior. Journal of Personality, v. 75, p. I286-1319, 2007.

MATSUMOTO, D. et al. Psychological culture, physical health, and subjective well-being. Journal of Gender, Culture, and Health, v. 4, p. I-I8, I999.

MCHOSKEY, J. W. Authoritarianism and ethical ideology. Journal of Social Psychology, v. I36, p. 709-7I7, I996.

MILL, J. S. Utilitarianism. London: Parker, Son and Bourn, I863.

MILLER, J. G. Culture and moral development. In: MATSUMOTO, D. (Ed.). The handbook of culture and psychology. Oxford: University Press, 200I. p. I5I- I70.

MOGHADDAM, F. M.; STUDER, C. Cross-cultural psychology: the frustrated gadfly's promises, potentialities, and failures. In: FOX, D.; PRILLELTENSKY, I. (Ed.). Critical psychology: an introduction. Thousand Oaks, CA: Sage, I997. p. I85-20I.

NORENZAYAN, A.; HEINE, S. J. Psychological universals: What are they and how can we know? Psychological Bulletin, v. I3I, n. 5, p. 763-784, Sep. 2005.

OSGOOD, C. E.; SUCI, G. J.; TANNENBAUM, P. H. The measurement of meaning. Chicago: University of Illinois Press, I957.

PIAGET, J. The moral judgment of the child. Oxford, England: Harcourt, Brace, I932.

POWER, F. C. The moral self in community. In: LAPSLEY, D. K.; NARVAEZ, D. (Ed.). Moral development, self, and identity. Mahwah, NJ, US: Lawrence Erlbaum Associates Publishers, 2004. p. $47-64$.

REST, J. R. The major components of morality. In: KURTINES, W. M.; GEWIRTZ, J. L. (Ed.). Morality, moral behavior, and moral development. New York: John Willey \& Sons, I984.

REYNOLDS, S. J. Moral awareness and ethical predispositions: investigating the role of individual differences in the recognition of moral issues. Journal of Applied Psychology, v. 9I, p. 233-243, 2006.

ROE, R. A.; ESTER, P. Values and work: empirical findings and theoretical perspective. Applied Psychology: An International Review. Special Issue: Values and Work, v. 48, p. I-2I, I999.

ROHAN, M. J. A Rose by Any Name? The values construct. Personality and Social Psychology Review, v. 4, p. 255-277, 2000.

ROHAN, M. J.; MAIDEN, W. Investigations into "value fit". Sydney, Australia: University of New South Wales, , 2000. Unpublished manuscript. 
ROHAN, M. J.; ZANNA, M. P. The "products of socialization": a discussion of self-regulatory strategies and value systems. In: COOPER, J.; DARLEY, J.M. (Ed.). Attribution and social interaction: the legacy of Edward E. Jones. Washington, DC: American Psychological Association, I998. p. 279-292.

ROHNER, R. P. Toward a conception of culture for cross-cultural psychology. Journal of Cross-Cultural Psychology, v. I5, p. III-I38, I984.

ROKEACH, M. The nature of human values. New York: Free Press, I973.

RYAN, R. M.; DECI, E. L. Self-determination theory and the facilitation of intrinsic motivation, social development, and well-being. American Psychologist, v. 55, p. 68-78, 2000.

SAGIV, L.; SCHWARTZ, S. H. Value priorities and subjective well-being: direct relations and congruity effect. European Journal of Social Psychology, p. I77-I98, 2000.

SCHAFER, R. Aspects of internalization. New York: International Universities Press, Ig68.

SCHWARTZ, S. H. Universals in the content and structure of values: theoretical advances and empirical tests in 20 countries. Advances in Experimental Social Psychology, v. 25, p. I-65, I992.

Beyond individualism/collectivism. New cultural dimensions of values. In: KIM, U. et al. (Ed.). Individualism and collectivism: theory, method, and applications. Thousand Oaks, CA, US: Sage Publications, I994. p. 85-II9.

Value priorities and behavior: applying a theory of integrated value systems. In: SELIGMAN, C.; OLSON, J. M.; ZANNA, M. P. (Ed.). The psychology of values: The Ontario Symposium. Hillsdale, NJ, England: Lawrence Erlbaum Associates, I996. v. 8, p. I-24.

A theory of cultural value orientations: explication and applications. Comparative Sociology,

v. 5, p. I37-I82, 2006.

SCHWARTZ, S. H.; BARDI, A. Value hierarchies across cultures. Taking a similarities perspective. Journal of Cross-Cultural Psychology, v. 32, p. 268-290, $200 \mathrm{I}$.

SCHWARTZ, S. H.; BILSKY, W. Toward a universal psychological structure of human values. Journal of Personality and Social Psychology, v. 53, n. 3, p. 550-562, I987.

SCHWARTZ, S.; BILSKY, W. Toward a theory of the universal content and structure of values: extensions and cross-cultural replications. Journal of Personality and Social Psychology, v. 58, n. 5 , p. 878-89I, I990.

SCHWARTZ, S. H. et al. Value priorities and social desirability: much substance, some style. British Journal of Social Psychology, v. 36, p. 3-I8, I997.

SINGH, B.; FORSYTH, D. R. Sexual attitudes and moral values: the importance of idealism and relativism. Bulletin of the Psychonomic Society, v. 27, p. I60-162, I989.

SKITKA, L. J. Do the means always justify the ends, or do the ends sometimes justify the means? A value protection model of justice reasoning. Personality and Social Psychology Bulletin, v. 28, p. 588-597, 2002.

SKITKA, L. J.; HOUSTON, D. A. When due process is of no consequence: moral mandates and presumed defendant guilt or innocence. Social Justice Research, v. I4, p. 305-325, 200 I.

SKITKA, L. J.; MULLEN, E. Understanding fudgments of fairness in a real-world political context: A test of the value protection model of justice reasoning. Personality and Social Psychology Bulletin, v. 28, p. I4I9-I429, 2002.

SMITH, M. B. Values, self, and society toward a humanist social psychology. New Brunswick, NJ: Transaction, I99I. 
SMITH, P. B.; SCHWARTZ, S. H. Values. In: BERRY, J. W.; SEGALL, M. H.; KAĞITC̨IBAȘI, Ç. (Ed.). Handbook of cross-cultural psychology. Boston: Allyn and Bacon, I997. v. 3, p. 77-II8.

TANGNEY, J. P. Self-conscious emotions: the self as a moral guide. In: TESSER, A.; STAPEL, D. A.; WOOD, J. V. (Ed.). Self and motivation: emerging psychological perspectives. Washington, DC: American Psychological Association, 2002. p. 97-II7.

TRIANDIS, H. C. The analysis of subjective culture. New York: Wiley, I972. Culture and social behavior. New York: McGraw-Hill, I994.

VERKASALO, M. et al. Protestant ethic value in the Schwartz value model in five countries. 2008. Unpublished manuscript.

WALKER, L. Gus in the Gap: Bridging the Judgment-Action Gap in Moral Functioning. In: LAPSLEY, D. K.; Narvaez, D. (Ed.). Moral development, self, and identity. Mahwah, NJ, US: Lawrence Erlbaum Associates Publishers, 2004. p. I-20.

WAN, C. et al. Perceived cultural importance and actual self-importance of values in cultural identification. Journal of Personality and Social Psychology, v. 92, p. 337-354, 2007.

WILSON, M. S. Social dominance and ethical ideology: the end justifies the means? Journal of Social Psychology, v. I43, p. 549-558, 2003.

WUENSCH, K. L.; POLEAT, G. M. Evaluating the morality of animal research: effects of ethical ideology, gender, and purpose. Journal of Social Behaviour and Personality, v. I3, p. I39-150, I998. ZAVALLONI, M. Values. In: TRIANDIS, H.; BRISLIN, R. (Ed.). Handbook of cross-cultural psychology. Boston: Allyn and Bacon, I980. v. 5, p. 73-I20. 